\title{
The Impact of Internal Attributes of Corporate Governance on Firm Performance
}

\author{
Abdul Karim \\ Lecturer, School of Accounting and Finance, Faculty of Management Studies, UCP \\ akarimicmacp@yahoo.com \\ Rida Faiz \\ Mphil Scholar \\ School of Accounting and Finance, Faculty of Management Studies, UCP
}

\begin{abstract}
This panel data is about leasing sector of Pakistan from 2011-2015. In this sector there are eleven companies. Which includes two dependent variables and four independent variables. Because there hasn't been any work done on this specific sector since 2008. The pooled ordinary least square method is used to estimates the models. Return on asset and return on equity are two dependent variables which are used to measure the performance of firms. Internal attributes of corporate governance are board size, ownership concentration, managerial concentration and outside directors. These attributes are also independent variables of this study. Corporate governance has very significance role in evaluation of firm's performance, which is discussed in detail by proving it empirically.
\end{abstract}

Keywords: corporate governance, leasing companies, internal attributes, Pakistani firms

\section{Introduction}

Corporate governance is very important for corporate sector of any country. It is the system that directs and controls the companies (committe, 1992). If company fails to comply with corporate governance, there are different sort of penance imposed to them as punishment. There are different attributes of corporate governance, which are used to check either companies are following them or not. In this study internal attributes of corporate governance are discussed to check whether they have any influence on company's performance or not. Internal attributes which are discussed in this article are as board size, outside directors on the board, managerial ownership, and ownership concentration to check their influence on performance of Pakistan leasing sector.

Board size has positive relationship with performance of firm, ownership concentration also has positive relation with performance of firms. This empirically result proves and supports the statement of (Vishny, 1986) that shareholders has an influence in corporate governance affairs and have effect on performance of firms. Outside directors have negative relationship with performance of firm. Because they are not full time employee of the company that's why they give less time to it. Managerial ownership also has negative relationship with firm's performance.

The next section is literature review about the internal attributes of corporate governance and their impact on firm performance specially leasing sector of Pakistan. Then there is empirical part which is about the research design. Then there is discussion on

The current issue and full text archive of this journal is available at www.jraspublications.org/index.php/JRAS/issue/archive

Journal of Research in Administrative Sciences

VI(II), 1-4, ISSN: 2664-2433 result. Limitations and recommendations of study. In the end, there is conclusion.

\section{Problem Statement}

There should be highest profit and there should be no decline in profit of leasing companies of Pakistan, however leasing firms of Pakistan has no high profit and most of the firms are suffering from loss. Therefore, this research is conducted on leasing sector of Pakistan to find out the impact of internal attributes of corporate governance on firms performance.

\section{Research Gap}

There is no study conducted on impact of internal attributes of corporate governance on firm's performance of leasing sector of Pakistan. Only one study was conducted on the data from 2004-2008 about internal attributes of corporate governance on firm's performance.

\section{Research Objectives}

Objective of our study is to find out the effect of internal attributes of corporate governance on firm's performance in case of leasing sector of Pakistan (2011-2015).

\section{Literature review}

There are different views of authors basis on their respective study about relationship of internal attributes of corporate governance with firm performance and their views are discussed here in this section of literature review. In some studies there are positive and in some studies there are negative relationship between internal 
attributes of corporate governance with firm's performance. Managerial ownership and outside directors has negative relationship on firms' performance (Sheikh, 2013). Performance of firm and internal mechanism of firm has negative relationship with each other (J, 2002). Internal attributes of corporate governance effects firm performance in negative and sometimes positive way (Turk2, 1990). It is impossible to conclude effect of managerial ownership with firm performance (Charles P. Himmelberga Darius Paliaa, 1999). There is significant negative relationship between profitability and board size (Theodore Eisenberga Stefan Sundgrenb, 1998). Outside directors has significant positive relationship with performance of firms (peng, 2004). No significant relationship between performance of firm and ownership concentration (Harold Demsetz, 2001).

\section{Theoretical Frame Work}

There are two dependent variables Return on Asset (ROA), Return on Equity (ROE), and four independent variables, which are Board Size (BS), Outside Directors (OD), Managerial Ownership (MO) and Ownership Concentration (OC). Return on asset, return on equity are used to determine performance of firms whereas remaining variables which are independent variables are used as internal attributes of corporate governance.

\section{Hypotheses}

$\mathbf{H}_{1}$ : There is significant positive relationship between internal attributes of corporate governance and return on asset of Pakistani leasing companies

$\mathbf{H}_{2}$ : There is significant negative relationship between internal attributes of corporate governance and return on equity of Pakistani leasing companies

\section{Research Methodology}

This research article is on leasing sector of Pakistan (2011-2015) This sector consists of eleven companies. This data is taken from websites of Pakistan stock exchange and state bank of Pakistan. The independent variables are outside directors, managerial owner ship, ownership concentration and board size. Pooled ordinary least square method is used to estimates the models. In table I there is description of data and definitions of all variables which are used in this study.

\begin{tabular}{|c|c|}
\multicolumn{2}{c}{ Description of Data Table I } \\
\hline $\begin{array}{c}\text { Return on Asset } \\
\text { (ROA) }\end{array}$ & Profit before taxes to total assets \\
\hline $\begin{array}{c}\text { Return on equity } \\
\text { (ROE) }\end{array}$ & $\begin{array}{c}\text { Profit before taxes to stockholders } \\
\text { equity }\end{array}$ \\
\hline Board Size (BS) & Total number of director of a firm \\
\hline $\begin{array}{c}\text { Outside directors } \\
\text { (OD) }\end{array}$ & $\begin{array}{c}\text { Outside directors to total directors of } \\
\text { firm }\end{array}$ \\
\hline $\begin{array}{c}\text { Ownership } \\
\text { concentration } \\
\text { (OC) }\end{array}$ & $\begin{array}{c}\text { Shares held by the five largest } \\
\text { shareholders to total shares }\end{array}$ \\
\hline $\begin{array}{c}\text { Managerial } \\
\text { ownership } \\
\text { (MO) }\end{array}$ & $\begin{array}{c}\text { Shares held by the CEOs, directors } \\
\text { and their family members to total } \\
\text { common shares }\end{array}$ \\
\hline
\end{tabular}

Ordinary least square method is used to estimates the models.

$\mathrm{ROE}=\beta_{0}+\beta_{1} \mathrm{BS}+\beta_{2} \mathrm{OC}+\beta_{3} \mathrm{MO}+\beta_{4} \mathrm{OD}+\mu$

$\mathrm{ROA}=\beta_{\circ}+\beta_{1} \mathrm{BS}+\beta_{2} \mathrm{OC}+\beta_{3} \mathrm{MO}+\beta_{4} \mathrm{OD}+\mu$

Where ROE is return on equity and ROA is return on asset both are dependent variables. BS is board size, OC is ownership concentration, MO is managerial ownership, and OD is outside directors whereas $\mu$ is an error term which represents all other unexplained factors which has effect on them but they are not included in this study. There empirical results and finding are discussed further.

\section{Empirical Results}

Descriptive statistics of dependent and independent variables used in this study are presented in Table II which shows average of return on asset and return on equity is 1.822 and 4.811

\begin{tabular}{|c|c|c|c|c|}
\hline Variables & Mean & SD & Minimum & Maximum \\
\hline ROA & $\begin{array}{c}1.82277 \\
8\end{array}$ & 3.301555 & -4.950000 & 7.481960 \\
\hline ROE & $\begin{array}{c}4.81184 \\
5\end{array}$ & 9.166161 & -14.00000 & 20.38000 \\
\hline BS & $\begin{array}{c}6.28000 \\
0\end{array}$ & 1.137248 & 5.000000 & 8.000000 \\
\hline OD & $\begin{array}{c}0.07300 \\
00\end{array}$ & 0.383039 & 0.000000 & 1.000000 \\
\hline $\mathrm{OC}$ & 0.5989 & 5.825439 & 511.5518 & $\begin{array}{c}12.96998 \\
8\end{array}$ \\
\hline MO & 0.21742 & 135.0307 & 0.000000 & 309.8049 \\
\hline
\end{tabular}

Average of outside directors is 7 percent on the board size and five biggest shareholders are average 59.89 percent holding total shares of firm. Which is highly significant, high value of ownership concentration represents weak legal environment in country. 21.74 percent shares are holding by CEO, director and their family. It means directors and their family has less ownership of shares as compare to other five biggest shareholders. So more voting rights in election of directors at annual meetings by shareholders who have 59.89 percent shareholding.

Standard deviation of return on asset is 3.301555 , return on equity is 9.166161. Which means how return on asset is 3.301555 and 9.166161 return on equity deviate from normal or disperse in data. Return on equity is more deviated from normal but return on asset is very few. Standard deviation of managerial ownership is highest and its value is 135.0307 . It means it is highly deviated from standards firm should need to worry and work on managerial ownership of firms. Remaining standard deviations of independent variables are up to standard. They are not much deviated. Which is a good sign.

\section{Regression Results}

During process of data analysis, two models of multiple regression were estimated. Empirically results are shown below in table III which includes effect of all other variables on return on asset. Board size has significant positive relationship to return on asset and outside directors has negative relationship to return on asset. Ownership concentration has positive and significant relationship to return on asset. Managerial ownership has negative relationship to the return on asset.

Table III

Effect of independent variables on ROA

\begin{tabular}{|c|c|c|c|c|}
\hline variables & Coefficie & SE & t-statistic & Prob. \\
\hline $\mathrm{C}$ & $\begin{array}{c}- \\
21.44591 \\
\end{array}$ & $\begin{array}{c}6.06557 \\
4 \\
\end{array}$ & $\begin{array}{c}- \\
3.535677 \\
\end{array}$ & 0.0021 \\
\hline BS & 3.689613 & $\begin{array}{c}1.20406 \\
0\end{array}$ & 3.064311 & 0.0061 \\
\hline OD & $\begin{array}{c}- \\
0.016375\end{array}$ & $\begin{array}{c}0.00324 \\
6 \\
\end{array}$ & $\begin{array}{c}- \\
5.043911\end{array}$ & 0.0001 \\
\hline $\mathrm{OC}$ & $5.33 \mathrm{E}-07$ & $\begin{array}{c}2.48 \mathrm{E}- \\
07\end{array}$ & 2.151916 & 0.0438 \\
\hline MO & $\begin{array}{c}- \\
0.868323\end{array}$ & $\begin{array}{c}3.56378 \\
3\end{array}$ & $\begin{array}{c}- \\
0.243652\end{array}$ & 0.8100 \\
\hline $\mathrm{R}^{2}$ & 0.79 & & $\begin{array}{l}\text { Mean of } \\
\text { dependen } \\
t \text { variable }\end{array}$ & 1.82 \\
\hline $\begin{array}{c}\text { Adjusted } \\
\mathrm{R}^{2}\end{array}$ & 0.75 & & $\begin{array}{l}\text { F-statistic } \\
\text { Prob. (F- } \\
\text { statistic) }\end{array}$ & $\begin{array}{l}19.92002 \\
0.000001\end{array}$ \\
\hline
\end{tabular}

\section{Descriptive Statistics Table II}


There are significant results of outside directors, ownership concentration, board size on return on asset but insignificant result of managerial concentration. Which means all describes independent variables have effect on return on asset but managerial ownership has not influence on return on asset of firms of leasing sector of Pakistan. Its p-values should be less than 0.05 percentage but it has 0.8100 which is highly insignificant. So in firms of leasing sector decision making on return on asset is not influencing by directors and their family members who are also shareholders of firm. $\mathrm{R}^{2}$ is 0.79 which is near highest, because maximum value of $\mathrm{R}^{2}$ should be 1 , as its range is $0-1$. It explained these all independent variables except managerial ownership has strong influence on dependent variable return on asset and there are very few variables left who influence return on asset but not included in this study. Pvalue tells about over all significance of model and in this model it is 0.000001 which is good, according to statistical standard which should be less than 0.05 percent. F-statistics tells about model is good fit.

Standard error of model should be as less as possible, because it tells accuracy of model. In this study standard error is 1 to 6 . Which means it is acceptable and it means model accuracy is very good.

\section{Effect of independent variables on ROE}

Table IV

\begin{tabular}{|c|c|c|c|c|}
\hline variables & Coefficient & SE & t-statistic & Prob. \\
\hline $\mathrm{C}$ & -15.07725 & $\begin{array}{c}11.898 \\
47\end{array}$ & $\begin{array}{c}- \\
1.267159\end{array}$ & 0.2197 \\
\hline BS & 1.345307 & $\begin{array}{c}2.3619 \\
31\end{array}$ & 0.569579 & 0.5753 \\
\hline MO & -0.037870 & $\begin{array}{c}0.0063 \\
68\end{array}$ & $\begin{array}{c}- \\
5.946604\end{array}$ & 0.0000 \\
\hline $\mathrm{OC}$ & $-9.22 \mathrm{E}-07$ & $\begin{array}{c}4.86 \mathrm{E}- \\
07\end{array}$ & $\begin{array}{c}- \\
1.898580\end{array}$ & 0.0721 \\
\hline OD & 27.03688 & $\begin{array}{c}6.9908 \\
58\end{array}$ & 3.867463 & 0.0010 \\
\hline $\mathrm{R}^{2}$ & 0.89 & & $\begin{array}{c}\text { Mean } \\
\text { dependen } \\
t \text { variable }\end{array}$ & $\begin{array}{c}4.81184 \\
5\end{array}$ \\
\hline $\begin{array}{c}\text { Adjusted } \\
\mathrm{R}^{2}\end{array}$ & 0.87 & & $\begin{array}{c}\text { F- } \\
\text { statistics } \\
\text { Prob. (F- } \\
\text { statistics) }\end{array}$ & $\begin{array}{c}44.9169 \\
1 \\
0.00000 \\
0\end{array}$ \\
\hline
\end{tabular}

Results of table IV is about effect of all independent variables on return on equity. Board size and outside directors have positive relationship with return of equity of firm and managerial ownership and owner ship concentration have negative relationship with return on asset.

$\mathrm{R}^{2}$ tells about effects and influence of explained variables in study, its range is between $0-1$ and 0.7 means high effects of independent variable on dependent variable and it means there are very few variables left which are not included in this study but they have influence on these dependent variables. F-statistics tells about over all good fitness of model and p-value tells about over all significance of model. Standard error should be as less as possible. In such results $\mathrm{p}$ value is less than 0.05 which means models are good fit and over all significant.

\section{Correlation}

Correlation tells about interdependence of variables. Weakness or strength of their relation with each other. In following table the correlation is shown. As shown in table $\mathrm{V}$ correlation between all variables is positive with each other. 1 means there is 100 percent correlation as board size with board size has 100 percent correlation. Correlation of board size with managerial ownership, outside directors, return on asset and return on equity is positive and with ownership concentration is negative. It means board size do not correlate with ownership concentration.

Managerial ownership has positive correlation with return on asset and board size but negative correlation with ownership concentration, outside directors and return on equity. According to these results it means managerial ownership do not correlate with ownership, outside directors and return on equity. Ownership concentration has negative correlation with board size, managerial ownership and return on equity. Positive correlation with outside directors and return on asset. Ownership concentration do not correlate with board size, managerial ownership and return on equity. Outside directors negatively correlated with managerial ownership and positive correlated with board size, ownership concentration, return on asset and return on equity. Outside directors do not participate in management affairs and have no shares of firm that is the reason it has not correlation with managerial ownership. Return on asset has positive correlation with all variables and return on equity has positive correlation with board size, outside directors and return on asset, but it has negative correlation with managerial ownership and owner ship concentration. It means managerial ownership and ownership concentration has not any influence on return on equity.

Table V

Correlation Results

\begin{tabular}{|c|c|c|c|c|c|c|}
\hline & BS & MO & OC & OD & ROA & ROE \\
\hline BS & 1 & 0.07850667951102603 & -0.271928136110 & 0.5877344282544595 & 0.237753074004465 & 0.2864413937927907 \\
\hline MO & 0.07850667951102603 & 1 & -0.027385923753 & -0.084864660781 & 0.08294787345356729 & -0.242479542671 \\
\hline OC & -0.271928136110 & -0.027385923753 & 1 & 0.4965534515870334 & 0.1592555500705019 & -0.08708910847 \\
\hline OD & 0.5877344282544595 & -0.084864660781 & 0.4965534515870334 & 1 & 0.1842023612241568 & 0.2266092370480389 \\
\hline ROA & 0.237753074004465 & 0.08294787345356729 & 0.1592555500705019 & 0.1842023612241568 & 1 & 0.02786715783562514 \\
\hline ROE & 0.2864413937927907 & -0.24247954267 & -0.087089108479 & 0.2266092370480389 & 0.02786715783562514 & 1 \\
\hline
\end{tabular}




\section{Limitations}

Data is taken from period of 2011-2015 and out of eleven leasing companies only seven companies are included in the study because data of four companies is not available. There is only one leasing sector of Pakistan is discussed in this study.

\section{Recommendations}

Any researcher can conduct research on same sector or different sector at different period of time on corporate governance attributes, especially in Pakistan there is so much search gap on this leasing sector in the context of corporate governance of Pakistan.

\section{Conclusions}

Board size has significant positive relationship with return on asset and outside directors has negative relationship with return on asset. Ownership concentration has positive and significant relationship with return on asset. Managerial ownership has negative relationship with return on asset. Board size and outside directors have positive relationship with return on equity of firm and managerial ownership and owner ship concentration has negative relationship with return on asset. So it is concluded that corporate governance plays a vital role in the performance of firms in Pakistan and these attributes have influence on firm performance.

\section{References}

i. Charles P. Himmelberga Darius Paliaa, c. (1999). Understanding the determinants of managerial ownership and the link between ownership and performance. Journal of Financial Economics.

committe, c. (1992).

ii. Harold Demsetz, a. ,. (2001). Ownership structure and corporate performance. journal of corporate finance.

iii. J, c. w. (2002). Internal and External Governance Mechanisms: Their Impact on the Performance of Large UK Public Companies.

iv. peng, m. w. (2004). Outside directors and firm performance during institutional transitions. the stratagic management journal.

v. Sheikh, N. A. (2013). The impact of internal attributes of corporate governance on firm performance.

vi. Theodore Eisenberga Stefan Sundgrenb, M. T. (1998). Larger board size and decreasing firm value in small firms1. Journal of Financial Economics.

vii. Turk2, R. E. (1990). Corporate Restructuring: Governance and Control Limits of the Internal Capital Market. academy of management journal.

viii. Vishny, S. a. (1986). Large Shareholders and Corporate Control . pp. pp. 461-488 . 